\title{
Soils sampled during a biological survey of the Western Australian wheatbelt
}

\author{
E.A. Griffin' and T.C. Stoneman ${ }^{2}$ \\ Department of Agriculture, Baron-Hay Court, South Perth, Western Australia 6167, Australia \\ 186 Whitfeld Street, Floreat, Western Australia 6014. Australia
}

\begin{abstract}
As part of a biodiversity survey, soil profiles are described and classified at 304 quadrats set in uncleared vegetation remnonts throughout the Western Australian wheatbelt.

The Department of Agriculture, Westem Australia, has developed a hierarchical soil-handscape GIS for the region. The Western Australian Soil Group layer in this classification was used to assess how well the 304 quadrats sampled the region's soils. The predominance of quadrats with sandy surface soils reflects the general nature of the region as well as the preferential clearing of its loamy and clayey soils for agriculture.

While soils of saline drainage lines were sampled more frequently than expected, given their regional extent, it was a deliberate strategy of the survey to sample areas where biodiversity is threatened by the effects of rising saline groundwater. On the other hand, some regionally common sandy soils such as Yellow deep sand and sandy earths were under-sampled, as were the regionally less common loamy and clayey soils.

In terms of wheatbelt soil-landscapes, the Lockier and Southern Cross areas were under-sampled while peripheral areas more typical of the forest than the wheatbelt were over-sampled

Some of this sampling bias would have been difficult to redress because the loamy and clayey soil groups and the Lockier area have been largely cleared for agriculture.
\end{abstract}

\section{INTRODUCTION}

\section{Overview of soils of south-western Australia}

South-westem Australia has long been recognized for having a predominance of sandy and infertile soils (McArthur, 1991). Traditional paradigms to explain these characters invoke deep weathering and planation over a long period, perhaps eons (Jutson, 1950; Mulcahy, 1973).

The major influences on soils are the soil parent material and the degree of weathering and landscape rejuvenation caused primarily by tectonic activity and climate change (Mulcahy, 1973; MeArthur et al., 1977; Tille th al., 2001). This recognition is the basis of small-scale soil mapping products (Prescott, 1931; Northcote of al., 1967; McArthur it al., 1977). These authors broadly recognize the dominance of the weathered acidic granitic shield with sandy sediments fringing its coastal margins. Areas of significant stripping, principally by water (Finkl and Churchward, 1973), are identified as such in the Zone of Rejurenated Drainage (Mulcahy and Hingston, 1961). These contrast with the drier Zone of Ancient Drainage with its limited stripping and sluggish drainage lines.
Vegetation type distribution has been explained as being determined by soil and climate (Gardner, 1944; Lange, 1960). These views are being challenged by Pate of al. (2000) who, through investigation of relationships between soil and native plants, invert this relationship. They provide evidence that many of the soil types in southwestern Australia are the product of plant exudates and the actions of micro-organisms. While the influence of root exudates in mineral weathering has long been recognized, the novelty lies in the active influence of particular plant groups, e.g. Proteaceat, in modifying their soil environment to their own advantage. They assert that these formation processes, being both long standing and contemporary, have contributed much to the planation.

No matter what the predominant soil formation process is, it is clear that plants and soil have a strong relationship. Early settlers recognized this (Moore, 1884 cited in McArthur, 1991) in their selection of land. The extension of agriculture into the wheatbelt continued largely based on vegetation types as a guide to the suitability of the land.

No accurate soil type map of south-western Australia has been prepared; only various 
representations of land tracts with different suites of soils. The Atlas of Australian Soils (Northcote et al., 1967) has been until recently the most detailed complete map (scale 1:2,000,000) of the soils of south-western Australia.

Landscape characteristics are a major component of recent soil-landscape mapping by the Department of Agriculture, Western Australia (Purdie, 1993). These 1:50,000 to 1:250,000 scale maps use an hierarchy of map units. A map of the dominant soils in south-western Australia (Schoknecht, 2002) represented on a consistent soillandscape systems unit (Purdie, 1993) has been a product of this programme.

An important small-scaled product is a soil- landscape zone map of south-western Australia in which the broad patterns of landscapes are indicated (Figure 1). These zones are convenient vehicles by which the broad soil and landscape characteristics can be communicated. They have modest correlation with the IBRA regions (see Figure 1 of McKenzie et al., 2004) but are units of a more detailed scale. Summary descriptions of these zones, including parent material, degree of stripping, and dominant soils, are provided in Table 1.

Figure 1, which shows these zones and average annual rainfall, suggests that climate has had a strong influence on geomorphology and soil development.

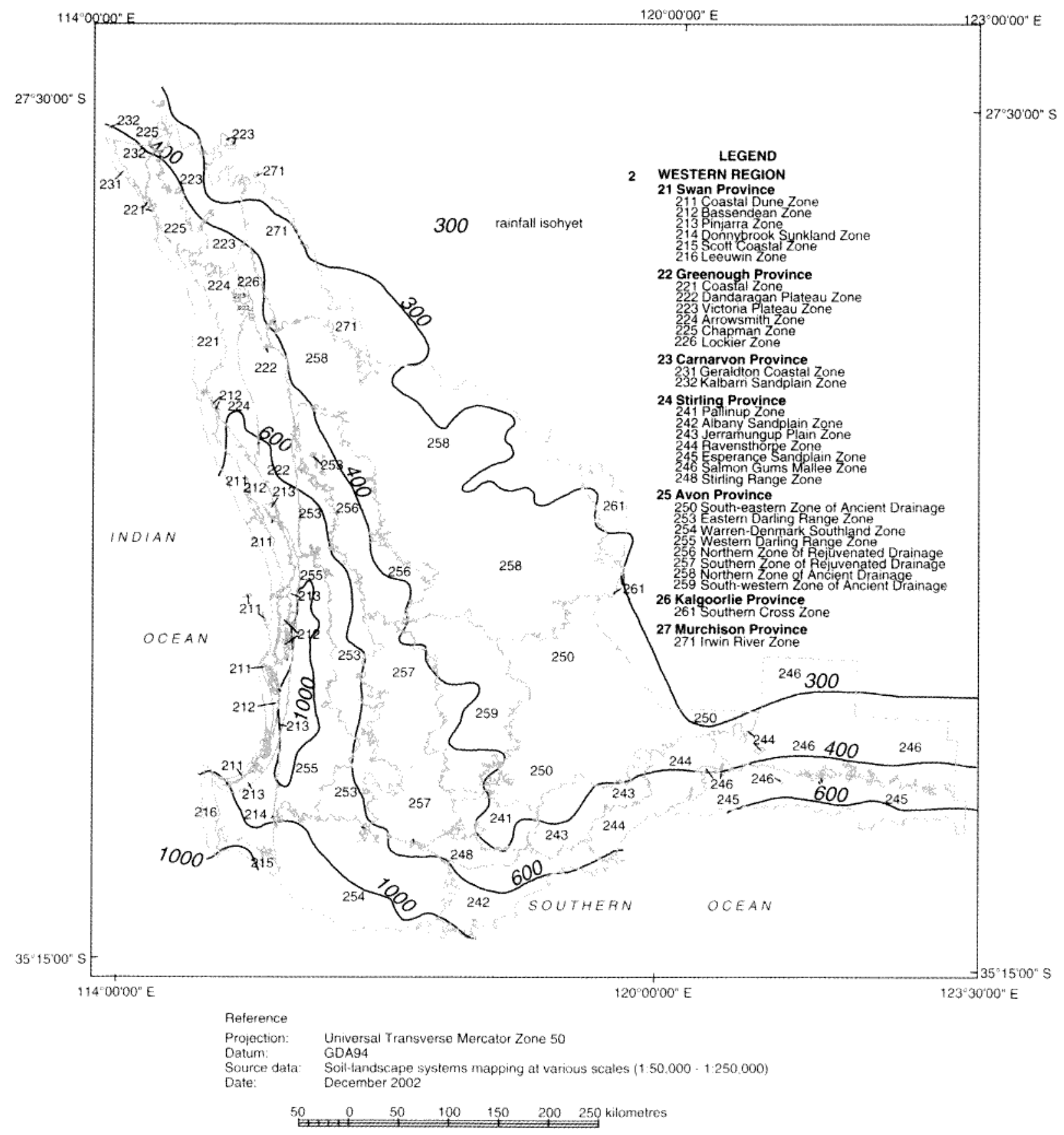

Figure 1 Soil-landscape zone map with rainfall isohyets. 


\section{Sampling for Salinity Action Plan}

This paper presents descriptions of the soils at each of the terrestrial biodiversity quadrats sampled during the Salinity Action Plan survey (McKenzie et al., 2004). A summary of the main soils sampled is provided. It includes an assessment of the representativeness of these quadrats, individually and collectively, in terms of the soils documented to occur in the wheatbelt during the Department of Agriculture's soil-landscape mapping programme. An attempt is also made to predict if any undersampled soils could have been found in extant native vegetation in the wheatbelt.

\section{METHODS}

\section{Soil sampling at survey quadrats}

The wheatbelt study area was divided into 24 survey areas (see Figure 1 in McKenzie et al., 2004). Twelve or 13 quadrats were established in each survey area, with each quadrat attempting to represent a different landscape or vegetation type. All were in apparently natural vegetation relatively unaffected by European activities. There was a deliberate pairing of some quadrats so that effects of rising saline ground waters might be examined.

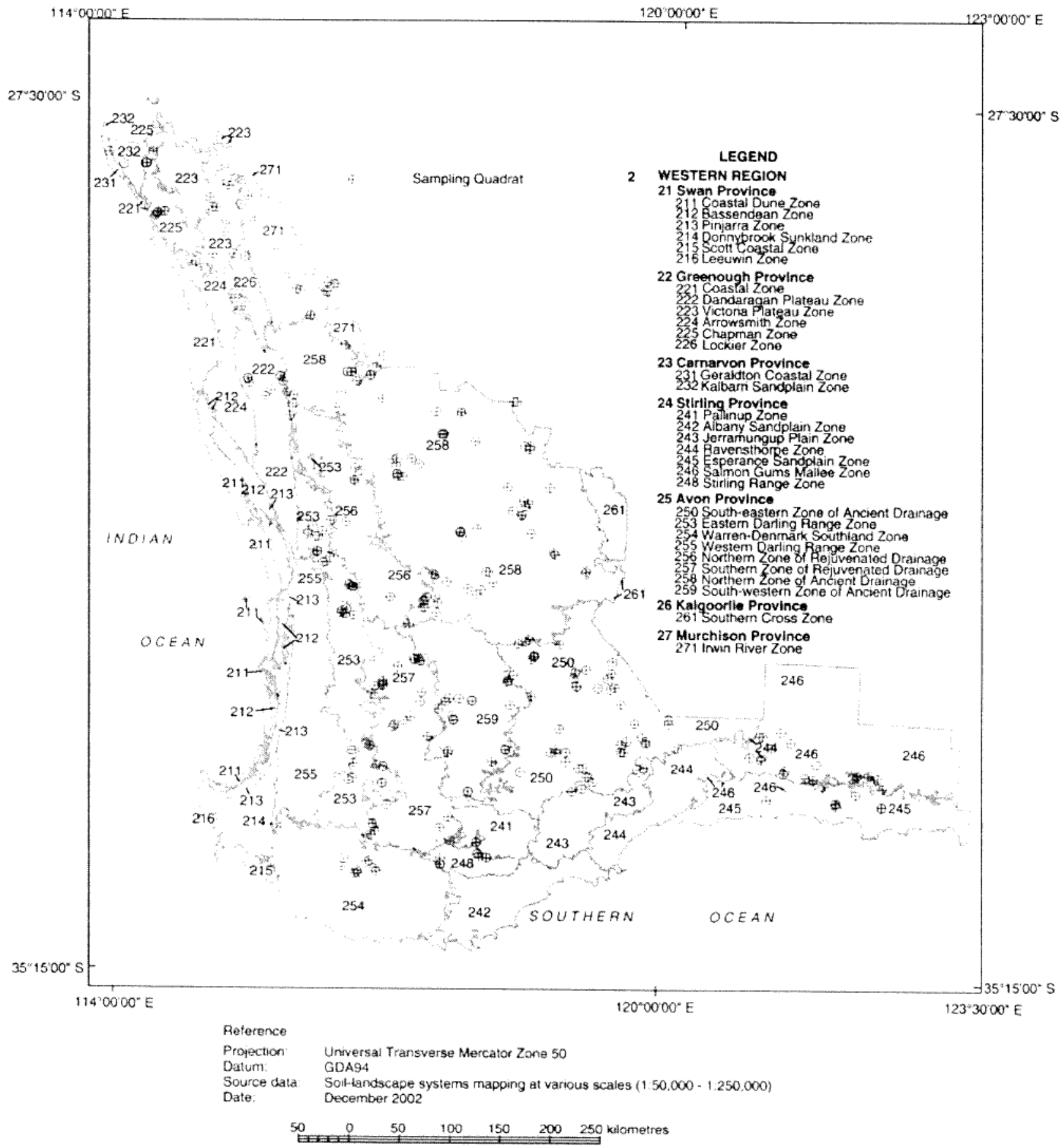

Figure 2 Sampling quadrat locations on soil-landscape zone map 
Table 1 Summary description of soil-landscape zones in south-western Australia (unpublished from Map Unit database, Department of Agriculture). Symbols that are underlined form the wheatbelt or have been sampled in this study.

\begin{tabular}{cll}
\hline Symbol & Zone name & Summary description \\
\hline 211 & Perth Coastal Zone & $\begin{array}{l}\text { Coastal sand dunes and calcarenite. Late Pleistocene to Recent. (Quindalup and } \\
\text { Spearwood systems). Calcareous and siliceous sands and calcarenite. }\end{array}$ \\
212 & Bassendean Zone & $\begin{array}{l}\text { Mid Pleistocene Bassendean sand. Fixed dunes inland from coastal dune zone. } \\
\text { Non-calcareous sands, podsolized soils with low-lying wet areas. }\end{array}$ \\
213 & Pinjarra Zone & $\begin{array}{l}\text { Alluvial deposits (early Pleistocene to Recent) between the Bassendean Dunes } \\
\text { Zone and the Darling Scarp, colluvial and shelf deposits adjacent to the Darling } \\
\text { Scarp. Clayey to sandy alluvial soils with wet areas. }\end{array}$
\end{tabular}

214 Donnybrook Sunkland Zone

Moderately dissected lateritic plateau on Perth Basin sedimentary rocks. Soils are formed in lateritic colluvium, weathered in-situ sedimentary rocks and alluvium (poorly drained sandy alluvial plain in the south).

215 Scott Coastal Zone

Pleistocene to Recent coastal barrier dunes and backplain. Non-calcareous sands dominate with podsolized soils with low-lying wet areas.

216 Leeuwin Zone

Leeuwin Block (tectonic geology), moderately dissected lateritic plateau on granite. Colluvial soils in the valleys. On the western margin the granite is overlain by Tamala Limestone and there are some coastal dunes.

Geraldton Coastal Zone Dunes with alluvial plains and sand sheets. Low hills of Pleistocene Tamala Limestone, Recent calcareous and siliceous dunes.

222 Dandaragan Plateau

Zone

Gently undulating plateau with areas of sandplain and some laterite. On Cretaceous sediments. Broad u-shaped valleys $80-150 \mathrm{~m}$ deep, smaller $v$-shaped east of the Gingin Scarp in the south. Soils are formed in colluvium and weathered rock.

223 Victoria Plateau Zone

Gently undulating sandplain on Silurian sandstone and Proterozoic granulite with laterite exposed at dissected margins.

224 Arrowsmith Zone

Dissected lateritic sandplain on Cretaceous and Jurassic sediments. Bounded in the east by the Dandaragan Scarp and in the south and west by the Gingin Scarp. Sandy and gravelly soils formed in colluvium and weathered in-situ rock.

Chapman Zone

Mesas of Triassic and Jurassic sediments on undulating Proterozoic granulite and migmatite with numerous dolerite dykes. Soils formed in in-situ weathered rock, and lateritic colluvium on the sedimentary rocks (mesas).

226 Lockier Zone

River valleys of the Irwin, Lockier and Arrowsmith rivers. Alluvial valley plains underlain by Proterozoic granulites, Permian and Jurassic sediments. Outliers of Victoria Plateau Zone occur within the zone. Clayey to silty soils.

231 Port Gregory Coastal

Coastal dunes, calcareous in places. Undulating sandplain on limestone Zone (Pleistocene calcarenite).

232 Kalbarri Sandplain Zone Undulating sandplain on Silurian and Devonian sediments of the Gascoyne Sub Basin (Carnarvon Basin), some Cretaceous sediments. Moderately dissected in places with laterite remnants.

241 Pallinup Zone

Undulating rises on Archaean granitic rocks in the Upper Pallinup catchment. Shallow duplex soils, commonly with sodic and alkaline subsoils. Woodlands of York and Salmon gums, wandoo and yate dominate.

Albany Sandplain Zone Gently undulating plain dissected by a number of short rivers flowing south Eocene marine sediments overlying Proterozoic granitic and metamorphic rocks. Soils are sandy duplex soils, often alkaline and sodic, with some sands and gravels.

243 Jerramungup Zone

Level to gently undulating plain dissected by a number of short rivers flowing south. On Eocene marine sediments overlying Proterozoic granitic and metamorphic rocks. Soils are alkaline sandy duplex soils with some clays, sands and gravels.

244 Ravensthorpe Zone

Rolling low hills on greenstone (mafic and ultramafic). Moderately dissected with south-flowing rivers. Red fine-textured soils.

$245 \quad$ Esperance Sandplain Zone

Level to gently undulating plain dissected by a number of short rivers flowing south. Formed on Eocene marine sediments overlying Proterozoic granitic and metamorphic rocks. Soils are grey fine sandy duplex soils and fine sands. 


\begin{tabular}{cl} 
Symbol & Zone name \\
\hline 246 & $\begin{array}{l}\text { Salmon Gums-Mallee } \\
\text { Zone: }\end{array}$
\end{tabular}

248 Stirling Range Zone

250 South-eastern Zone of Ancient Drainage

254 Warren-Denmark Southland Zone

255 Western Darling Range Zone

Northern Zone of Rejuvenated Drainage

257 Southern Zone of Rejuvenated Drainage

Northern Zone of Ancient Drainage

South-western Zone of Ancient Drainage

Southern Cross Zone
Summary description

Level to gently undulating plain, with Tertiary sediments over Proterozoic granites. Salt lakes, scattered or in swarms are a common feature. Drainage lines become indistinct towards the north.

Mountains on metasediments with associated rises and poorly drained plains to the north. Rocky and gravelly soils occur the mountains and sandy duplexes on the rises and plain. Shrublands dominate the mountains and woodlands the rises

A smooth to irregularly undulating plain dominated by salt lake chains in the main valleys with duplex and lateritic soils on the uplands. Mallee vegetation on duplex soils, proteaceous vegetation on gravels and sands.

Moderately to strongly dissected lateritic plateau on granite with some surficial Eocene sediments. Soils are formed in laterite colluvium or weathered in-situ granite. Minor streams tend to be eastward-flowing.

Rises in a series of broad benches from the Southern Ocean north to the Blackwood Valley. Deeply weathered granite and gneiss overlain by Tertiary and Quaternary sediments in the south. Swampy in places.

Moderately dissected lateritic plateau on granite with deeply incised valleys, includes the Darling Scarp on the western margin. Soils are formed in laterite, lateritic colluvium and weathered in-situ granite and gneiss.

Erosional surface of gently undulating rises to low hills. Continuous stream channels that flow in most years. Colluvial processes are active. Soils formed in colluvium or in-situ weathered rock. Mainly from Jimperding Metamorphic Rocks.

Erosional surface of gently undulating rises to low hills. Continuous stream channels that flow in most years. Colluvial processes are active. Soils formed in colluvium or in-situ weathered rock.

An ancient plain with low relief on weathered granite. There is no connected drainage, salt lake chains occur as remnants of ancient drainage systems which now only function in very wet years. Lateritic uplands dominated by yellow sandplain

An ancient plain of low relief on weathered granites with sluggish drainage systems and uplands dominated by sands and gravels. Lateritic uplands dominated by grey sandy gravel plain predominately with proteaceous species.

Rises and low hills on Archaean greenstones, with broad valleys often containing salt lake chains. Soils are usually red, loamy to clayey and calcareous.

The Irwin and Lockier River catchments within the Yilgarn Craton. Archaean granites, gneisses, metasediments and basic igneous rocks.
At each of the 304 quadrats (Figure 2) landscape and soil descriptions were made using Department of Agriculture, Western Australia, standards which are based on McDonald et al. (1990). These edaphic descriptions provide opportunities for correlations with the observed biota to be examined. The standardized observations made allow potential extension of biological findings to areas not sampled through the point and polygon datasets of the Department of Agriculture.

Soil profiles were described from hand auger borings, made to a depth of about $1 \mathrm{~m}$ where possible. The morphological characters/properties recorded included colours, field textures, coarse fragments, structure, mottles, and the presence of root limiting layers such as pans. Field $\mathrm{pH}$ of most layers was determined using an Inoculo Soil pH kit. Soil profiles were classified into Western Australian
Soil Groups (Schoknecht, 2002) and the Australian Soil Classification (ASC) (Isbell, 2002). The latter was often tentative due to the absence of all of the required laboratory data. Tenosols, which require little or no laboratory data, are probably quite reliable. However, the distinction between Chromosols and Sodosols and many lower levels of the classification require laboratory data for reasonable certainty. Some morphological property correlations and geographic and landscape distributions often assisted in guessing the likely ASC Soil Order.

Samples of layers were taken for laboratory analysis at all quadrats. Financial constraints restricted analysis to one representative subsoil layer from each quadrat. The analyses included $\mathrm{pH}$, electrical conductivity, chloride, calcium carbonate and gypsum content and were conducted by the 
1. Regions

Broad subdivisions of the Australian continent (Bettenay 1983).

e.g. The Western Region (2)

\section{Provinces}

Provide a broad overview of the whole state suitable for maps at scales of about 1:5,000,000 (Bettenay 1983).

e.g. The Avon Province (25)

\section{Zones}

Areas defined on geomorphologic or geological criteria, suitable for regional perspectives.

e.g. South-western Zone of Ancient Drainage (259)

\section{Systems}

Areas with recurring patterns of landforms, soils and vegetation, suitable for regional mapping at scales of 1:250,000.

e.g. Kukerin System (259Kk)

\section{Subsystems}

Areas of characteristic landforms features containing definite suites of soils, suitable for mapping at regional scales of 1:100,000.

e.g. Kukerin 1 Subsystem (259Kk_1)

\section{Subsystem phases}

Division of subsystems based on land use interpretation requirements.

e.g. Kukerin 1 sandy phase (259Kk_1s)

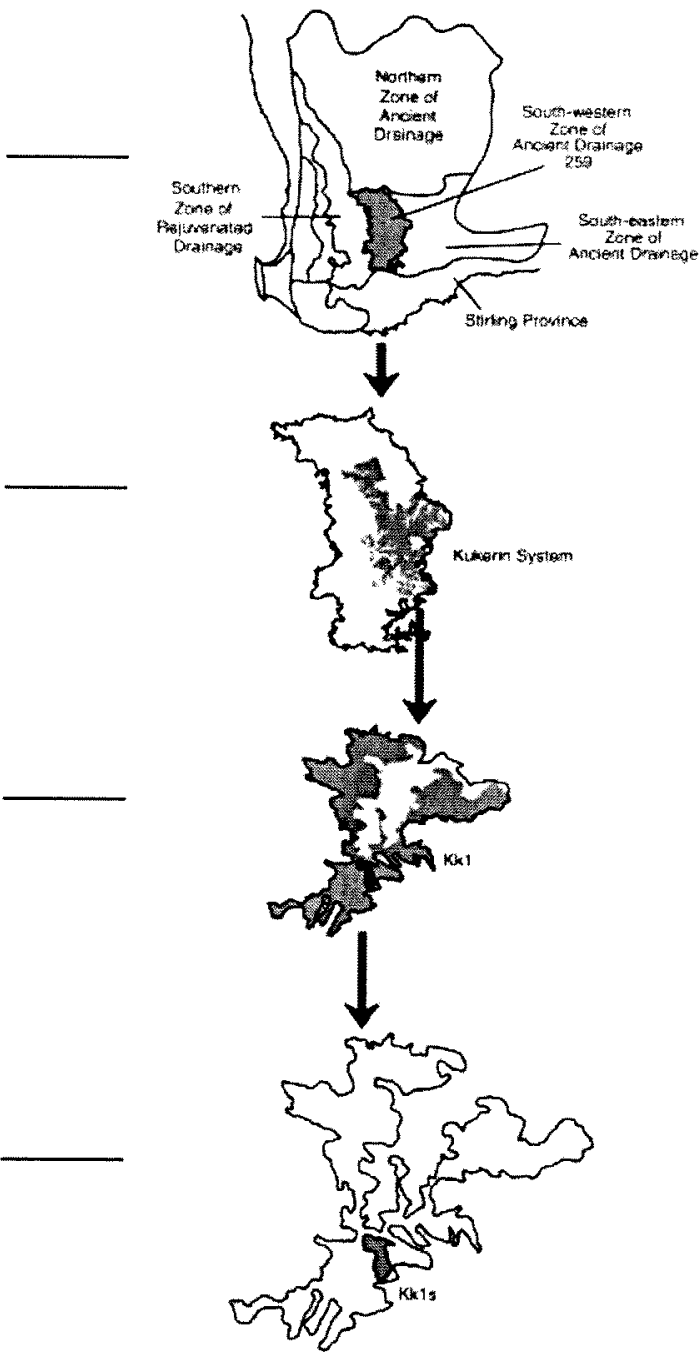

7. Land units (unmapped at regional scale)

Describe areas of land with similar soils, slopes and landforms.

Figure 3 Soil-landscape map unit hierarchy used by the Department of Agriculture. 
Department of Conservation and Land Management laboratories. Some of the samples were analyzed by the Chemistry Centre of WA for clay and organic carbon content as part of a study of soil organic carbon (Griffin and Schoknecht. 2002). Methods used are briefly outlined in Appendix 1.)

Bulked soil samples were also taken at depths of between $50-100 \mathrm{~mm}$ from a $30 \mathrm{~m} \times 30 \mathrm{~m}$ vegetation plot within each of the terrestrial biodiversity quadrats (see Methods in McKenzie et al., 2004). These 0.5 to $1 \mathrm{~kg}$ samples were analyzed by the Chemistry Centre of WA for pH, EC, organic carbon, total $\mathrm{N}$ and $\mathrm{P}$, bicarbonate extractable $\mathrm{P}$ and $\mathrm{K}$, as well as exchangeable cations, gypsum and calcium carbonate (see Appendix 3 in Mckenzie et al., 2004).

The descriptions of individual quadrats and their profiles have been incorporated into the Soil Profiles database of the Department of Agriculture, Western Australia. This contains over 50,000 similar observations, mostly from south-western Australia.

\section{Analysis of representativeness}

The soil units used for the analyses in this paper are Western Australian Soil Groups (Schoknecht, 2002) rather than the Australian standard (Australian Soil Classification, Isbell 2002) (ASC). Soil Groups were developed by the Department of Agriculture as a standard way for describing the soils of Western Australia, particularly those in the State's south-west. Sixty Soil Groups in 13 Super Groups are recognized. All 60 are quite general units, each of which represents many different soil types, used for land-use communication. The Soil Groups' virtues include ease of recognition and simplicity in concepts such as uniform, gradational and texture contrast profile types used in the system of Northcote (1979) plus soil colours and gravel content.

The ASC is a system widely used in land resource assessment in Australia but its adoption is limited in Western Australia. It has been used in the definition of major soil types (soil series), e.g. Percy (2000). Schoknecht (2002) shows that there are some broad relationships between the ASC and Soil Groups, but the significant differences between these systems restrict its use for mapping soil units in Western Australia

The Department of Agriculture's regional soillandscape mapping was used for comparison of the soil sampled at the quadrats. While there is complete coverage by this mapping for southwestern Australia, only about half has been published (e.g. Percy, 2000), and much was in draft form at the time of analysis (e.g. Verboom and Galloway, 2004). All mapping has descriptions and soil attribution and is being progressively reviewed. The soil-landscape maps are hierarchial, with a number of ranks that recognize different levels of complexity in soil, parent material and landscape (Purdie, 1993). Figure 3 provides an example of the hierarchy. The most detailed mapped units are typically subsystems and phases but are systems in some areas. All these units are heterogeneous and are partially characterized by the proportional allocation of Soil Groups by landscape position, e.g. Grey shallow sandy duplex on a footslope.

The soil-landscape hierarchy provides a number of levels at which soil and landscape data can be presented and interpreted. Soil-landscape zones provide useful units to represent the major geomorphic character and soils of south-western Australia (e.g. Figure 1). As a map unit they are similar to IBRA subregions (Cummings. and Hardy, 2000) in their intended scale of use.

The soil-landscape map unit in which each of the quadrats occurred was determined by a geographic information system (GIS) spatial query. Combining these data it was possible to determine what soils were considered characteristic of the wheatbelt and identify areas and soils that might have been underor over-sampled by the quadrats.

There are several reasons why the soil type observed at a quadrat can be different from that expected on the basis of the soil-landscape mapping. All mapping is affected by landscape heterogeneity, soil sampling intensity and soil mapping scale. The observed soil type may belong to a different land tract that was overlooked during the mapping programme, or be rare at local, general or at all scales of mapping in an area.

Determining just how well a quadrat's soil represented the map unit in which it fell was, therefore, somewhat problematical. Uncertainties included the classification of the soil at the quadrats and the allocation of soils to a map unit. The latter was influenced by the accuracy of the mapping and the knowledge of the soil types in the map unit. Thus comparisons were made at several mapping scales to gain an overall assessment.

Firstly, the comparison was made at the map unit, soil-landscape system and soil-landscape zone levels. These were all valid map units of different rank directly related to the individual quadrats. Secondly, to try to accommodate the likelihood of some differences in the soil classification, comparisons were made at both the soil group level and the super-group level. More weighting was given to the soil group than to the super group.

For each level of mapping, each quadrat was assigned to one of several levels of representativeness based on score classes of common, frequent, similar, uncommon, rare and not recorded. These were a somewhat arbitrary ranking with qualitative meaning only.

Only a small fraction $(<1 \%)$ of vegetation remnants in the wheatbelt could be sampled using 304 
Table 2 Expected percentage occurrence of different Soil Groups in soil-landscape zones, with the number of quadrats sampled in brackets. Table cells shaded grey indicate Soil Groups in zones that appear to be over-sampled (\% of sampled quadrats in zone for Soil Group > twice the proportion of soil predicted for zone). Table cells that are outlined in black indicate Soil Groups in zones that appear to be under-sampled (\% of sampled quadrats in zone of Soil Group < half the proportion of soil predicted for zone and soil predicted in $>5 \%$ of zone). Soil Groups shaded grey appear to be oversampled, whereas those outlined in black appear to be under-sampled..

Soil-landscape zone code \% of zone

\begin{tabular}{|c|c|c|c|c|c|c|c|c|c|c|}
\hline Code & Soil Group or Super Group & $\begin{array}{r}\text { Total } \\
\text { quads }\end{array}$ & 222 & 223 & 225 & 226 & 231 & 232 & 241 & 243 \\
\hline 100 & Wet or waterlogged soils & 1 & & & & & & & & \\
\hline 101 & Saline wet soil & 20 & 1 & 1 & 0 & 1 & & 0 & 3 & 5 \\
\hline 102 & Salt lake soil & 12 & 0 & (1) & & & 7 & & 0 & \\
\hline 103 & Semi-wet soil & 5 & 1 & 0 & & 0 & & & $(1)$ & 3 \\
\hline 104 & Tidal soil & & & & & & & & & \\
\hline 105 & Wet soil & 5 & 0 & & $(2)$ & & 0 & $0(1)$ & 0 & \\
\hline 201 & Bare rock & & 0 & 0 & 2 & 0 & & 0 & 4 & 4 \\
\hline 202 & Calcareous stony soil & & 0 & & & & & & & \\
\hline 203 & Stony soil & 1 & 0 & 0 & $0(1)$ & 1 & & 2 & 0 & 1 \\
\hline 300 & Ironstone gravelly soils supergroup & 1 & & & & & & & & \\
\hline 301 & $\begin{array}{l}\text { Deep sandy gravel } \\
\end{array}$ & 7 & 7 & & & 0 & & & $0(1)$ & 1 \\
\hline 302 & Duplex sandy gravel & 5 & 5 & 0 & 1 & 0 & & & 5 & 0 \\
\hline 303 & Loamy gravel & 2 & 0 & & & 1 & & & 0 & \\
\hline 304 & Shallow gravel & 23 & 3 & 2 & $2(1)$ & 1 & & 8 & 2 & 0 \\
\hline 400 & Sandy duplexes supergroup & & & & & & & 7 & & \\
\hline 401 & Alkaline grey deep sandy duplex & 2 & 0 & & & & & & 3 & 2 \\
\hline 402 & Alkaline grey shallow sandy duplex & 16 & $0(1)$ & & & & 1 & & 12 & 9 \\
\hline 403 & Grey deep sandy duplex & 18 & $1(2)$ & 1 & 2 & 0 & & 0 & 12 & 7 \\
\hline 404 & Grey shallow sandy duplex & 15 & 0 & $(1)$ & & & & & $13(1)$ & 15 \\
\hline 405 & Red deep sandy duplex & 8 & 0 & 2 & 0 & $3(1)$ & & & 0 & \\
\hline 406 & Red shallow sandy duplex & 11 & 0 & $0(1)$ & 10 & 1 & & & 3 & \\
\hline 407 & Yellow/brown deep sandy duplex & 5 & 0 & & 1 & 1 & & & 1 & 0 \\
\hline 408 & Yellow/brown shallow sandy duplex & 6 & 0 & 0 & 7 & 0 & 1 & & 1 & 0 \\
\hline 409 & Reticulite deep sandy duplex & & & & & & & & & \\
\hline 421 & Calcareous shallow sand & & & & & & 10 & & & \\
\hline 422 & Pale shallow sand & 12 & $1(1)$ & $0(1)$ & 0 & 0 & & 3 & 0 & 1 \\
\hline 423 & Red shallow sand & 2 & 0 & & & 0 & 3 & & & \\
\hline 424 & Yellow/brown shallow sand & 10 & 0 & $0(1)$ & & & 17 & & & \\
\hline 440 & Deep sands supergroup & 1 & & & & & & & & \\
\hline 441 & Brown deep sand & & 3 & & 0 & 0 & & & 0 & \\
\hline 442 & Calcareous deep sand & 2 & & & & & $33(1)$ & & & \\
\hline 443 & Gravelly pale deep sand & 2 & 10 & 4 & 1 & 0 & & 5 & 0 & 0 \\
\hline 444 & Pale deep sand & 22 & $22(4)$ & $1(1)$ & $2(1)$ & 0 & & 31 & 2 & 3 \\
\hline 445 & Red deep sand & & 3 & 2 & & 2 & & & & \\
\hline 446 & Yellow deep sand & 22 & 30 & $57(2)$ & $12(2)$ & 9 & 22 & 33 & & 0 \\
\hline 460 & Sandy earths supergroup & & & & & & & & & \\
\hline 461 & Acid yellow sandy earth & & & & & & & & & \\
\hline 462 & Brown sandy earth & 2 & 0 & & & & & & 0 & \\
\hline
\end{tabular}


occupied by Soil Group (number of quadrats)

\begin{tabular}{|c|c|c|c|c|c|c|c|c|c|c|c|c|c|c|}
\hline 244 & 245 & 246 & 248 & 250 & 253 & 254 & 255 & 256 & 257 & 258 & 259 & 261 & 271 & RGE \\
\hline & & & & (1) & & & & & & & & & & \\
\hline 2 & $2(1)$ & $0(1)$ & 2 & $4(2)$ & $2(2)$ & $2(1)$ & \multirow[t]{2}{*}{2} & $3(1)$ & $3(1)$ & $3(6)$ & $7(5)$ & 0 & 2 & \\
\hline & $O(1)$ & $8(1)$ & $5(1)$ & $7(3)$ & 0 & (1) & & (1) & 0 & $2(3)$ & 0 & 1 & 1 & \\
\hline 2 & $0(2)$ & (1) & 4 & 0 & 1 & $7(1)$ & 3 & 0 & 0 & 0 & & & 0 & \\
\hline
\end{tabular}

\begin{tabular}{|l|l|l|l|l|l|l|l|l|l|l|l|l|l|}
\hline 0 & $(1)$ & & 0 & 0 & $1(1)$ & 11 & 4 & 1 & 0 & 0 & 0 & \\
\hline 6 & 1 & 0 & 2 & 1 & 3 & 0 & 2 & 2 & 3 & 2 & 0 & 0 & 0 \\
\hline
\end{tabular}

\begin{tabular}{|c|c|c|c|c|c|c|c|c|c|c|c|c|c|}
\hline 4 & & 0 & 12 & 0 & 1 & 1 & 2 & 0 & 0 & 2 & 0 & & 3 \\
\hline & & & & 0 & 1 & & (1) & & 0 & & & & \\
\hline 1 & 0 & & 0 & $1(2)$ & $14(1)$ & 4 & $3(1)$ & $1(1)$ & 3 & $O(1)$ & 4 & 3 & \\
\hline 2 & & & $13(3)$ & 2 & 9 & 13 & $17(1)$ & 0 & 8 & $3(1)$ & 6 & & \\
\hline 0 & & & 1 & $O(1)$ & 16 & 18 & 18 & 3 & $2(1)$ & 3 & 4 & 0 & 1 \\
\hline 6 & $5(1)$ & $1(1)$ & 6 & $2(5)$ & $7(5)$ & $4(1)$ & 4 & $1(3)$ & $2(2)$ & $2(2)$ & $6(1)$ & & $2(1)$ \\
\hline
\end{tabular}

\begin{tabular}{|r|r|}
\cline { 2 - 3 } 0 & 5 \\
\hline 23 & 0 \\
\hline 10 & $37(2)$ \\
\hline 14 & 14 \\
\hline
\end{tabular}

\begin{tabular}{|r|r|}
\hline 3 & 3 \\
\hline $48(4)$ & $2(1)$ \\
\hline 0 & 16 \\
\hline $0(1)$ & $8(1)$ \\
\hline
\end{tabular}

\begin{tabular}{|l|l|l|l|}
\hline $3(1)$ & 0 & 0 \\
\hline
\end{tabular}

\begin{tabular}{|r|r|r|r|r|r|r|r|}
\hline & $3(1)$ & 0 & 3 & 4 & 1 & & \\
\hline 1 & 0 & 1 & $5(1)$ & $13(2)$ & 2 & & \\
\hline $0(2)$ & 11 & $26(6)$ & $4(4)$ & $12(1)$ & & 0 & \\
\hline 0 & 5 & $7(3)$ & $0(1)$ & $3(1)$ & 1 & & \\
\hline 0 & 4 & 0 & $0(5)$ & $0(1)$ & 0 & 1 & $(1)$ \\
\hline 1 & 1 & 0 & $0(5)$ & 0 & $1(3)$ & $5(2)$ & $(2)$ \\
\hline 2 & 1 & $6(1)$ & $0(2)$ & 1 & 0 & 0 & \\
\hline & 0 & $2(1)$ & $0(3)$ & 1 & & 2 & \\
\hline & 0 & 0 & & 1 & & & \\
\hline
\end{tabular}

3

\begin{tabular}{r|r|r|r|}
\hline 0 & 0 & 0 & 0 \\
\hline 0 & 0 & 0 & 0 \\
\hline 2 & $3(2)$ & 0 \\
\hline $2(2)$ & 0 & \\
\hline & 0 & 0 &
\end{tabular}

\begin{tabular}{l:l}
0 & \\
\hline &
\end{tabular}

\begin{tabular}{|c|c|c|c|c|c|c|c|c|c|c|c|c|c|}
\hline 2 & 0 & 0 & 2 & $0(2)$ & $O(2)$ & 0 & 0 & 1 & $O(1)$ & $O(1)$ & $0(4)$ & & \\
\hline & & & & 0 & 0 & & & 0 & 0 & $0(2)$ & 0 & & 7 \\
\hline (1) & & & 0 & $4(4)$ & 0 & & 0 & 3 & $O(1)$ & $0(2)$ & 0 & 3 & (1) \\
\hline
\end{tabular}

\section{(1)}

\begin{tabular}{|l|l|l|l|l|l|l|l|l|l|l|l|l|}
\hline 0 & & 0 & 0 & 1 & 0 & 0 & 0 & 3 & 0 & 1 & 2 & 0 \\
\hline 5 & $(1)$ & & & & 1 & & & & 0 & & & \\
\hline
\end{tabular}

\begin{tabular}{|c|c|c|c|c|c|c|c|c|c|c|c|c|c|}
\hline & 5 & (1) & & & & 1 & & & & 0 & & & \\
\hline 0 & & & 0 & $O(1)$ & 2 & 0 & 2 & 2 & 1 & $O(1)$ & 2 & & 0 \\
\hline 6 & $20(1)$ & $8(1)$ & $5(2)$ & $2(1)$ & $1(6)$ & $5(3)$ & 2 & 3 & $2(2)$ & 0 & 1 & 1 & \\
\hline & & & & & & 0 & & & & 0 & & & 0 \\
\hline & & & & $2(2)$ & $0(2)$ & $4(1)$ & 3 & 2 & $0(2)$ & $8(8)$ & $1(2)$ & 3 & $11(1)$ \\
\hline & & & & & & & & & & & & & 0 \\
\hline & & & & 0 & & & & & & 4 & & 0 & 0 \\
\hline 0 & & & 0 & 3 & 0 & & 0 & 5 & 0 & $1(2)$ & & 3 & 1 \\
\hline
\end{tabular}


Table 2 (cont.)

\begin{tabular}{|c|c|c|c|c|c|c|c|c|c|c|}
\hline \multirow[b]{2}{*}{ Code } & \multirow[b]{2}{*}{ Soil Group or Super Group } & \multirow[b]{2}{*}{$\begin{array}{l}\text { Total } \\
\text { quads }\end{array}$} & \multirow[b]{2}{*}{222} & \multicolumn{7}{|c|}{ Soil-landscape zone code $\%$ of zone } \\
\hline & & & & 223 & 225 & 226 & 231 & 232 & 241 & 243 \\
\hline 463 & Red sandy earth & & 0 & 3 & 3 & 1 & & & & \\
\hline 464 & Yellow sandy earth & 5 & $1(1)$ & 7 & 0 & 2 & & 1 & & \\
\hline 465 & Pale sandy earth & 2 & 0 & & & & & & & \\
\hline 500 & Loamy duplexes supergroup & & & & & & & & & \\
\hline 501 & Acid shallow duplex & 5 & & & & & & & 0 & 1 \\
\hline 502 & Alkaline grey shallow loamy duplex & 11 & & & & & & & 10 & $16(1)$ \\
\hline 503 & Alkaline red shallow loamy duplex & 7 & & & & 7 & & & 3 & 1 \\
\hline 504 & Grey shallow loamy duplex & 6 & 0 & & & & & & 4 & 8 \\
\hline 505 & Brown deep loamy duplex & 1 & 0 & & & 0 & & & & \\
\hline 506 & Red deep loamy duplex & 3 & 0 & & $1(1)$ & 0 & & & 0 & 3 \\
\hline 507 & Red shallow loamy duplex & 8 & 0 & & $21(1)$ & 6 & & 2 & 1 & 4 \\
\hline 508 & Yellow/brown shallow loamy duplex & 1 & 0 & & & 2 & & & 1 & 0 \\
\hline 520 & Shallow loams supergroup & 1 & & & & & & & & \\
\hline 521 & Calcareous shallow loam & & 0 & & & & & & & \\
\hline 522 & Red shallow loam & & 0 & & 10 & 5 & & & & \\
\hline 523 & Red-brown hardpan shallow loam & & & 9 & 0 & 6 & & & & \\
\hline 540 & Loamy earths supergroup & 1 & & & & & & & & \\
\hline 541 & Brown loamy earth & & 0 & & 0 & 1 & & & & \\
\hline 542 & Calcareous loamy earth & 7 & 0 & 0 & & 7 & & & 1 & \\
\hline 543 & Friable red/brown loamy earth & & & & & & & & & \\
\hline 544 & Red loamy earth & 2 & 0 & 2 & 11 & 6 & 1 & & & \\
\hline 545 & Yellow loamy earth & & 0 & & & 0 & & & & \\
\hline 601 & Hard cracking clay & & 0 & & & 18 & 0 & & 1 & 1 \\
\hline 602 & Self-mulching cracking clay & & 0 & & 2 & 0 & & & 0 & \\
\hline 621 & Grey non-cracking clay & 3 & 0 & & & 3 & & & 1 & 4 \\
\hline \multirow[t]{2}{*}{622} & Red/brown non-cracking clay & 2 & & & 0 & 0 & & & 2 & 1 \\
\hline & Total & 304 & 9 & 8 & 10 & 1 & 1 & 1 & 3 & 1 \\
\hline & & & 222 & 223 & 225 & 226 & 231 & 232 & 241 & 243 \\
\hline
\end{tabular}

quadrats. It was, therefore, considered useful to evaluate whether any apparently under-sampled soils were likely to be represented in the wheatbelt's remnant areas of native vegetation. While this knowledge was not available directly, a GIS intersection of remaining vegetation (Shepherd et al., 2001) with the regional soil-landscape mapping provided an approximation. This involved determining the apparent area of remnant vegetation in each of the most detailed soil-landscape map units. By assuming that the remnant vegetated areas in a map unit had the same proportion of soil types as did the map unit as a whole, the area of each of these poorly sampled soils in remaining vegetation in each zone was calculated.
The results of such analysis need to be interpreted with caution for a number of reasons. Firstly, the remnant vegetation layer in the GIS is an interpretation from satellite imagery, and includes areas of disturbed vegetation, sometimes in very poor condition. Secondly, the vegetated portion of a soil-landscape unit is assumed to have the same soils as the map unit as a whole. In many cases this will not be true because clearing has been biased towards soils of higher agricultural productivity. Thus a conservative evaluation was made of just the soils that were expected to occur in at least $5 \%$ of a zone and were poorly sampled by this study (i.e. sampled at either 0 or 1 quadrat). 
occupied by Soil Group (number of quadrats)

\begin{tabular}{|c|c|c|c|c|c|c|c|c|c|c|c|c|c|c|}
\hline 244 & 245 & 246 & 248 & 250 & 253 & 254 & 255 & 256 & 257 & 258 & 259 & 261 & 271 & RGE \\
\hline & & & & & 0 & & 0 & 1 & 0 & 2 & & 0 & 1 & \\
\hline & & & & $1(1)$ & 0 & 0 & 2 & 6 & 0 & $11(3)$ & 1 & 1 & 8 & \\
\hline & & & & & 0 & 0 & 0 & 0 & 0 & $0(1)$ & $0(1)$ & & & \\
\hline & & & & & 0 & & & & & & & & & \\
\hline & & & & 0 & $0(1)$ & 0 & 0 & 0 & $1(1)$ & $2(3)$ & 2 & & & \\
\hline & & $2(1)$ & 1 & $4(6)$ & & & & $0(1)$ & 0 & 0 & $3(2)$ & 0 & & \\
\hline & & & & 0 & 0 & & & 0 & 0 & $4(5)$ & 1 & 4 & $0(1)$ & (1) \\
\hline 0 & 0 & & 2 & $0(1)$ & 0 & 0 & 0 & 1 & $2(3)$ & $O(1)$ & 1 & & & \\
\hline & & & 0 & & 4 & 3 & 3 & 0 & $2(1)$ & 0 & 0 & & 0 & \\
\hline & & & & 0 & 1 & & 0 & 4 & 0 & 0 & 0 & 1 & $0(2)$ & \\
\hline & & (1) & & 0 & $1(1)$ & 0 & 0 & $2(1)$ & $2(2)$ & $0(2)$ & 0 & 1 & 2 & \\
\hline & & & 1 & $O(1)$ & 1 & 1 & 3 & 3 & 1 & 3 & 1 & & 0 & \\
\hline & & (1) & & & 0 & & & 0 & & 0 & & & & \\
\hline 0 & & & & & 0 & 0 & 0 & 1 & 0 & 4 & 0 & & 4 & \\
\hline & & & & 0 & & & & & & 0 & & 1 & 20 & \\
\hline & & & & 0 & (1) & & & & 0 & & 0 & & & \\
\hline & & & 1 & 1 & 2 & 1 & 4 & 5 & 1 & 1 & 0 & 1 & 2 & \\
\hline 3 & 0 & $22(1)$ & & $7(2)$ & & & & 0 & 0 & $8(4)$ & 2 & 23 & 2 & \\
\hline & & & & 0 & 1 & 6 & 5 & 0 & 0 & 0 & 0 & & & \\
\hline & & 0 & 0 & 0 & 0 & 0 & 3 & 1 & 0 & 1 & 0 & 7 & $11(2)$ & \\
\hline & & & & 0 & 0 & & 0 & 0 & 0 & 0 & & & 0 & \\
\hline & & 1 & & 0 & 0 & & & 0 & 0 & 1 & 1 & 6 & 0 & \\
\hline & & & & 0 & 0 & & 0 & 1 & 0 & 0 & 0 & & 0 & \\
\hline 1 & 1 & $O(1)$ & 0 & $2(2)$ & 0 & & 0 & 0 & 0 & 0 & 1 & & & \\
\hline 4 & & & 0 & 1 & 0 & 0 & & 2 & 0 & $1(1)$ & 2 & 22 & 0 & (1) \\
\hline 1 & 9 & 16 & 8 & 49 & 29 & 9 & 5 & 9 & 28 & 70 & 20 & 0 & 10 & 6 \\
\hline 244 & 245 & 246 & 248 & 250 & 253 & 254 & 255 & 256 & 257 & 258 & 259 & 261 & 271 & RGE \\
\hline
\end{tabular}

\section{RESULTS}

\section{Soils sampled}

A standard report generated from the Department of Agriculture's Soil Profiles database is provided for each of these quadrats (Appendix 1). Appendix 2 is a listing of the 304 quadrats showing the Soil Group and the soil-landscape map unit in which each falls. A coding is also provided which tries to indicate how well each quadrat's Soil Group matched that expected to occur in the map unit, in its parent soil-landscape system, and in its parent soil-landscape zone. Sandy surfaced soils were predominant amongst the quadrats. Clayey and loamy surfaced soils were represented by small numbers of quadrats.
Westem Australian Soil Grotus

The soils at the quadrats were from 39 Soil Groups and five Super Groups (used when it was not possible to identify a Soil Group) (Table 2). Twelve of the thirteen Super Groups in the classification system were represented by these quadrats. The predominant Super Groups sampled were Deep sands, Sandy duplexes and Wet or waterlogged soils. The most common Soil Groups sampled were Shallow gravel, Pale deep sand, Yellow deep sand, Saline wet soil, Grey deep sandy duplex, Alkaline grey shallow sandy duplex, Grey shallow sandy duplex, Alkaline grey shallow sandy duplex, Grey shallow sandy duplex, Salt lake soil, Pale shallow sand, Red shallow sandy duplex, 
Table 3 Number of quadrats sampled in each Australian Soil Classification Soil Order.

\begin{tabular}{lcl}
\hline Order & quadrats & Main Suborders \\
\hline Anthroposol & - & \\
Calcarosol & 7 & Supracalcic \\
Chromosol & 79 & Yellow, Grey, Red and Brown \\
Dermosol & 2 & \\
Ferrosol & 2 & \\
Hydrosol & 32 & Hypersalic, Salic, Oxyaquic \\
Kandosol & 9 & Red, Yellow \\
Kurosol & 6 & Red, Grey \\
Organosol & - & \\
Podosol & - & \\
Rudosol & 10 & Leptic \\
Sodosol & 49 & Grey, Red \\
Tenosol & 108 & Yellow-Orthic, Sesqui-nodular, \\
& & Bleached-Orthic \\
Vertosol & 1 & \\
\hline
\end{tabular}

Alkaline grey shallow loamy duplex and Yellow/ brown shallow sand.

Table 2 also presents the expected proportion of each zone occupied by each soil (from Map Unit database, Department of Agriculture). A comparison of the number of quadrats sampled in each zone with these data identifies the zones where particular soils may have been under- or over-sampled.

Ten per cent of Soil Groups appear to have been over-sampled compared to the understanding from the mapping. These include Salt lake soil, Semi-wet soil, Wet soil, Red deep sandy duplex, Pale shallow sand and Yellow/brown shallow sand). On the other hand, $30 \%$ of Soil Groups appear to have been under-sampled, including Grey deep sandy duplex, Duplex sandy gravel, Alkaline grey shallow sandy duplex, Grey shallow sandy duplex, Yellow deep sand, Yellow sandy earth, Red-brown hardpan shallow loam, Calcareous loamy earth and Red loamy earth.

\section{Australian Soil Classification}

Each soil sampled in the present survey was classified using Isbell (2002) (Appendices 1,2). Most of the ASC Soil Orders were represented by the quadrats sampled (Table 3 ). Tenosols, Chromosols and Sodosols predominated as is typical for southwestern Australia (Isbell et al., 1997). The apparent of abundance of Hydrosols, however, appears to be an over-representation for the wheatbelt.

The distribution of Soil Orders by soil-landscape zones was briefly investigated. However, the disproportionate number of quadrats in each zone prevented more than brief observations to be made. Tenosols are widespread in most zones of southwestern Australia including the wheatbelt. Chromosols are also widespread, particularly in the wheatbelt. Sodosols are also important but more localized. Their main occurrences are in the southeastern and eastern portions of the wheatbelt (Zones 250 and 258).

\section{Geographic and landform representativeness of quadrats}

Most of the 24 survey areas were predominantly in a single soil-landscape zone but few were exclusively so. Each survey area had quadrats from at least three soil-landscape systems and together these systems represented at least two major landforms. This supports the intention for each survey area to represent a range of landscapes. Some soil-landscape systems were sampled by more than one survey area. Thus, survey areas sampled overlapping portions of the edaphic environment and to some degree are likely to be arbitrary geographic groupings of quadrats. This

Table 4 Soil-landscape system area and number of quadrats

\begin{tabular}{lcccc}
\hline System Area class & * quadrats & *systems & Av $=$ quadrats/system & Av $\approx$ quadrats $/$ Mha \\
\hline$>500 \mathrm{~K}$ ha & 62 & 8 & 7.8 & 11 \\
$<500 \&>300 \mathrm{~K}$ ha & 36 & 5 & 5.2 & 21 \\
$<300 \&>100 \mathrm{~K}$ ha & 113 & 36 & 3.1 & 18 \\
$<100 \mathrm{~K}$ ha & 93 & 47 & 2.0 & 66 \\
\hline
\end{tabular}

Table 5 Number of quadrats present in each of the landforms that comprise soil-landscape systems. Landform categories are broadly based on Landform Pattern sensu Speight (1990).

\begin{tabular}{lcccc}
\hline Landform & * quadrats & * systems & Av quadrats/system & Av $\#$ quadrats $/ \mathbf{M h a}$ \\
\hline Mountains & 2 & 1 & 2 & 16 \\
Low hills & 60 & 19 & 3.2 & 46 \\
Rises & 84 & 30 & 2.8 & 84 \\
Sandplains & 48 & 14 & 3.4 & 44 \\
Plains & 28 & 11 & 2.5 & 27 \\
Alluvial plain & 43 & 14 & 3.0 & 34 \\
Alluvial plain, saline $>30 \%$ & 39 & 7 & 5.6 & 37 \\
\hline
\end{tabular}


Table 6 Quadrats per unit area of system, by landform and system area class (Av \# quadrats/Mha). Landform categories are broadly based on Landform Pattern sensu Speight (1990).

\begin{tabular}{lcccc}
\hline Landform & $>500 \mathrm{~K}$ ha & $<500->300 \mathrm{~K}$ ha & $<300->100 \mathrm{~K}$ ha & $<100 \mathrm{~K}$ ha \\
\hline Mountains & 21 & & 16 & 65 \\
Low hills & 4 & 16 & 20 & 51 \\
Rises & 7 & 15 & 19 & 70 \\
Sandplains & 16 & 9 & 6 & 193 \\
Plains & 8 & 33 & 42 & 57 \\
Alluvial plain & & & 22 & 38 \\
Alluvial plain, saline $>30 \%$ & & & & \\
\hline
\end{tabular}

implies that biological differences based on aggregating quadrats into survey area units should be interpreted cautiously.

The 304 quadrats were located in 188 different map units (mostly of subsystem rank, but also some phases) from 96 systems (Appendix 2). Of these systems, Kwolyin, Lagan, Wallambin, Scaddan, Coblinine, Boyagin, Bonnie Rock and Newdegate had more than seven quadrats each. The systems with most quadrats tended to have been sampled by two or more survey areas. There was a tendency for the larger systems to have more of the quadrats (Table 4). However, of the systems with quadrats, several of the larger ones were relatively poorly sampled (e.g. Tandagin and Halbert).

The systems with quadrats can be grouped into a number of broad landforms (Table 5). These data show that saline alluvial plain systems (e.g. Lagan, Wallambin and Coblinine) had about twice the number of quadrats per system as did systems of other landforms. This was not just related to the area of these systems. Table 6 shows that there were many more quadrats on saline alluvial plains of systems in the area classes ' 100 to $300 \mathrm{~K}$ ha' and ' 300 to $500 \mathrm{~K}$ ha'.

Of the soil-landscape zones sampled, Northern Zone of Ancient Drainage (258) had the greatest number of quadrats (70, Table 7). However based on their area, Zones 248, 225, 253, 257 and 250 had relatively more quadrats than did other zones. On a similar area basis, Zones 261, 244, 243, 255, 254 , $226,256,232$ and 246 had very low numbers of quadrats. Many of these zones are on the margin of the wheatbelt and could be expected to be have been poorly sampled in this study. It could also be argued that two of them are not typical wheatbelt areas and should not have been sampled: WarrenDenmark Southland (254) and Western Darling Range (255). However, some typical wheatbelt zones had low sampling densities: Southern Cross (261), Lockier (226) and Salmon Gums-Mallee (246).

Table 7 Number of quadrats in soil-landscape zones.

\begin{tabular}{llccc}
\hline Symbol & Soil-landscape zone & area (K ha) & quadrats & Av $;$ quadrats/Mha \\
\hline RGE & (rangeland area, not assigned yet) & - & - \\
261 & Southern Cross Zone & 249 & 0 & 0 \\
243 & Jerramungup Zone & 542 & 1 & 2 \\
244 & Ravensthorpe Zone & 606 & 1 & 2 \\
255 & Western Darling Range Zone & 1177 & 5 & 4 \\
226 & Lockier Zone & 164 & 1 & 6 \\
254 & Warren-Denmark Southland Zone & 1576 & 9 & 8 \\
232 & Kalbarri Sandplain Zone & 125 & 1 & 8 \\
246 & Salmon Gums-Mallee Zone & 1887 & 16 & 8 \\
256 & Northern Zone of Rejuvenated Drainage & 1137 & 9 & 9 \\
241 & Pallinup Zone & 330 & 3 & 11 \\
245 & Esperance Sandplain Zone & 1021 & 9 & 12 \\
271 & Irwin River Zone & 871 & 10 & 12 \\
222 & Dandaragan Plateau Zone & 735 & 9 & 13 \\
223 & Victoria Plateau Zone & 688 & 8 & 16 \\
258 & Northern Zone of Ancient Drainage & 5404 & 70 & 20 \\
259 & South-western Zone of Ancient Drainage & 1262 & 20 & 20 \\
250 & South-eastern Zone of Ancient Drainage & 2503 & 49 & 21 \\
257 & Southern Zone of Rejuvenated Drainage & 1409 & 28 & 26 \\
253 & Eastern Darling Range Zone & 1266 & 29 & 34 \\
231 & Port Gregory Coastal Zone & 290 & 1 & 38 \\
225 & Chapman Zone & 210 & 8 & \\
248 & Stirling Range Zone & & & \\
& & & & \\
\end{tabular}


Table 8 Summary of representation classification by map unit, by system and by zone.

\begin{tabular}{|c|c|c|c|c|c|c|c|}
\hline From & Quadrats & common & frequent & $\begin{array}{l}\text { Ranking } \\
\text { similar }\end{array}$ & $\begin{array}{l}\text { Class } \\
\text { uncommon }\end{array}$ & rare & not recorded \\
\hline \multirow[t]{2}{*}{ Mapped Unit } & Number & 44 & 44 & 30 & 55 & 49 & 81 \\
\hline & $\%$ of 303 & 15 & 15 & 10 & 18 & 16 & 27 \\
\hline \multirow[t]{2}{*}{ System } & Number & 23 & 61 & 37 & 63 & 78 & 41 \\
\hline & $\%$ of 303 & 8 & 20 & 12 & 21 & 26 & 14 \\
\hline \multirow[t]{2}{*}{ Zone } & Number & 19 & 50 & 37 & 87 & 101 & 9 \\
\hline & $\%$ of 303 & 6 & 17 & 12 & 29 & 33 & 3 \\
\hline
\end{tabular}

\section{Representativeness at map unit level}

Soils of quadrats that were common or frequent at the map unit level were often at least frequent at the system or zone level. At all levels of analysis (either mapping scales or soil classification rank), less than a third of the quadrats had soils that were considered common or frequent in the mapped unit, the system or the zone in which they occurred. On the other hand, more than $50 \%$ were uncommon, rare or not previously recorded (Table 8 ). While this suggests that the quadrats are skewed towards the less common soils, no test of significance was performed.

There appeared to be systematic differences in the analysis from the different levels of mapping. At the mapped unit level, more of the soils tended to be either common, or not previously recorded compared to the assessment for systems and particularly for zones. This is explainable in terms of the characteristics of these map units. The most detailed levels of the mapping hierarchy tend to contain few soils, all of which are relatively common. They may contain small inclusions of different soils which are often not recognised because of their rare occurrence. Thus the likely result is a high proportion of soils not previously recorded at the mapped unit level. Systems and Zones, however, are the amalgamation of different mapped units and tend to be more heterogeneous with fewer soils being common. They contain many more soils from often quite different map units. Thus, as in this analysis, the number of soils not previously recorded for these units will be less compared to the detailed mapping.

\section{Potential to find poorly sampled soils in remnant vegetation}

The areal extent of indigenous vegetation remaining in each zone varied from over $50 \%$ (Zones 246 and 248) to less than 10\% (Zones 226, 256 and 259) (Table 9). These data reflect the differential clearing of the south-western Australia. Of the typical wheatbelt areas (Zones 223, 225, 226, 250, 256, $257,258,259,261$ and 271), only Zones 250 and 261 have retained significant areas of native vegetation. Both are on the eastern margin of the wheatbelt.

A number of Soil Groups that were at least moderately abundant in a zone according to the mapping ( $>5 \%$ coverage) were poorly sampled by quadrats in the same zone. These amounted to $11.4 \%$ (72) of the combinations of Soil Group by zone from 35 Soil Groups and 18 zones (Table 9). For each of these, a code has been inserted in the Table to indicate the proportion of the zone that is expected to be the particular Soil Group. The inferred area of each combination is also shown. All of these apparently poorly sampled and relatively important soils appear to occur in remnant vegetation in their respective zones, varying from small areas to hundreds of thousand hectares. Those with large areas are probably real, but those with small areas could be artefacts of the analysis or mapping.

Table 10 is an attempt to summarise these data. It shows that more than half of these combinations are of Soil Groups that are $<10 \%$ of the zone and may have been difficult to find, even in areas which had significant remnant vegetation. Nearly a third of occurrences in Table 9 appear to have much $(>10,000 \mathrm{ha})$ vegetation in the indicated Soil Group in the relevant zone. This includes Soil Groups from a range of zones; the Dandaragan Plateau Zone (222 - Yellow deep sand and Gravelly pale deep sand), the Kalbarri Sandplain Zone (232 - Pale deep sand), the Jerramungup Zone ( 243 - Grey shallow sandy duplex), the Esperance Sandplain Zone (245 - Pale deep sand and Grey shallow sandy duplex), the Salmon Gums-Mallee Zone (246 - Calcareous loamy earth), the Stirling Range Zone (248 - Stony soil and Grey deep sandy duplex), the Eastern Darling Range Zone (253 - Deep sandy gravel and Loamy gravel), the Southern Cross Zone (261 Calcareous loamy earth and Red/brown noncracking clay) and the Irwin River Zone (271 - Redbrown hardpan shallow loam). Except for the Irwin River Zone, all have more than a $25 \%$ coverage of native vegetation. Of these, only the Southern Cross and Irwin River Zones are core wheatbelt areas.

On the other hand, about a third of these 72 occurrences have little or very little vegetation. These are some of the poorly sampled Soil Groups from Lockier Zone (226), Port Gregory Coastal Zone (231), Chapman Zone (225), Northern Zone of Rejuvenated Drainage (256), Kalbarri Sandplain Zone (232), Stirling Range Zone (248), South- 
Table 9 Expected area of remnant native vegetation for under-sampled soils, by Soil Group and soil-landscape zone.

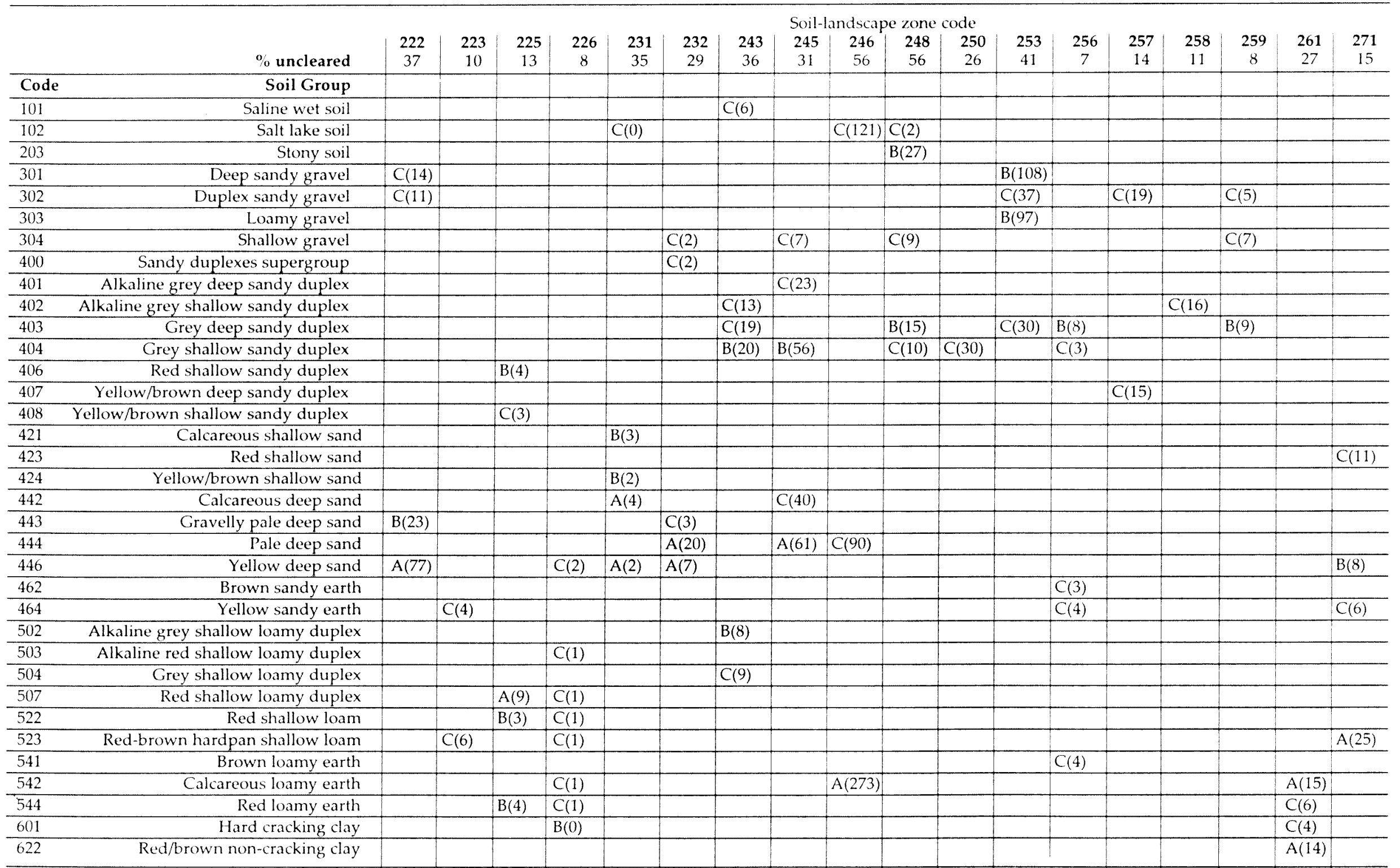

Cell values; A, B, C coding of expected area of Soil Group in zone, A - 20-80\% of zone, B - 10-20\%, C - 5-10\%. In brackets is apparent area of Soil Group in vegetation (K ha)

Under-sampled Soil Groups had one or no quadrats in the particular zone and from the soil mapping were expected to occupy at least $5 \%$ of the zone.

Empty cells are either soils which had a number of quadrats in the zone or were expected to occupy $<5 \%$ of the zone. 
Table 10 Summary of importance of under-sampled soil by area of Soil Group with vegetation. Summarized from Table 9

\begin{tabular}{|c|c|c|c|c|}
\hline \multirow[b]{2}{*}{ Vegetation on Soil Group in zone } & \multicolumn{3}{|c|}{ Relative importance of soil in zone } & \multirow[b]{2}{*}{ Total } \\
\hline & $A(20-100 \%)$ & B $(10-20 \%)$ & $C(5-10 \%)$ & \\
\hline Much $(>10,000$ ha $)$ & 7 & 7 & 15 & 29 \\
\hline Some $(5,000-10,000 \mathrm{ha})$ & 2 & 4 & 9 & 15 \\
\hline Little $(1,000-5,000 \mathrm{ha})$ & 2 & 5 & 13 & 20 \\
\hline Very little $(<1,000$ ha $)$ & & 1 & 7 & 8 \\
\hline All & 11 & 17 & 44 & 72 \\
\hline
\end{tabular}

western Zone of Ancient Drainage (259) and Victoria Plateau Zone (223). Many of these are typical wheatbelt zones. The Lockier Zone, for example, was both poorly sampled (only one quadrat) and virtually all of its common soils have very little remnant vegetation because most of its soils had agricultural potential and are cleared. Twenty of the 35 soils in this table had low or very low apparent areas of vegetation. Most of these soils are loamy or clayey surfaced soils (e.g. Alkaline grey shallow loamy duplex, Calcareous loamy earth and Hard cracking clay).

\section{DISCUSSION}

The virtue of sampling the biota of most of the major soils in different parts of the wheatbelt is undeniable. However, the task of obtaining comprehensive and representative sampling is substantial. To sample just once in each of the Soil Groups that apparently occupy $5 \%$ or more of each of the 18 soil-landscape zones covering the present study area would require about 100 quadrats. This overlooks the fact that, each Soil Group is a broad concept that often, for example, makes no distinction between many soils with alkaline, calcareous, acid or sodic subsoils, so several hundred additional quadrats would have been needed to represent the major soil variations just once. Therefore, with funding for only 304 quadrats available under the current study, it would have been nearly impossible to achieve a comprehensive coverage of soils.

Locating a representative range of soils, particularly the less common ones, is a difficult task anywhere, let-alone in natural vegetated remnants. Nevertheless, it was still instructive to evaluate just how well the wheatbelt's soils were sampled. The 304 quadrats included 39 of the 60 Soil Groups, most of which are present in the wheatbelt. Those either not sampled or poorly sampled tended to be from the loamy or clayey surfaced soils. Their low frequency of sampling is not surprising as these soils are those most likely to have been cleared for agriculture. The analysis showed that these appeared to have only a small potential to exist in native vegetation; they were unlikely to be readily available in extant remnant vegetation. On the other hand, some of the more common soils were undersampled (in terms of low numbers of quadrats in relation to the area occupied by the soil). In some zones these included soils such as Yellow deep sand. Most of these appeared to have remnant vegetation available for sampling.

A parallel aim of the sampling program was to document some of the biodiversity in areas under threat from the effects of advancing salinity, which is more pronounced on valley floors. Sampling was, therefore, skewed towards soils of wet and saline valley floors. These areas were deliberately sampled more than the interfluves, with additional quadrats on the valley floors representing salt-affected examples of these environments. In addition, quadrats were sampled on the margin of the wheatbelt to provide comparison. The quadrats around Lake Muir (in Zones 254 and 255) are examples.

The data were too few to conclusively define poorly sampled parts of the wheatbelt. However, two small soil-landscape zones stand out in this regard. The Lockier Zone (near Mingenew) had just one quadrat, but it appears that there was very little remnant vegetation in good condition to sample. On the other hand, the Southern Cross Zone, an area dominated by greenstone parent material on the eastern edge of the study area, was not sampled even though there are significant areas of native vegetation in that zone. The apparent over-sampling of Zones 254 and 255 was a product of deliberate sampling of valley floors mentioned above.

Although a number of common sandy soils were under-represented, the relatively few loamy or clayey soils sampled during the study is more concerning. These are now rare in wheatbelt remnants, and even in pre-European times would not have been common. It is probable that significant vegetation types on these soils may have been over-looked. Finding and managing suitable examples should be a conservation priority.

\section{ACKNOWLEDGEMENTS}

Trevor Stoneman made all field descriptions. Ted Griffin analysed the quadrat soils in terms of soil 
map data held by the Department of Agriculture. The data on field sheets were entered into the Profiles Database by Mary D'Souza. Phil Coulding undertook the GIS intersections and prepared the figures. We thank Richard Harper and Neil McKenzie for their comments on the manuscript. Funding for this study was provided as part of the State Salinity Strategy.

\section{REFERENCES}

Bettenay, E. (1983). Western Region (II). In Soils: an Australian viewopoint: 179-187. CSIRO, Melbourne

Cummings, B. and Hardy, A. (2000). Revision of the interim biogeographic regionalisation for Australia (IBRA) and development of version 5.1: summary report. Environment Australia, Canberra.

Gardner, C.A. (1944). The vegetation of Western Australia with special reference to climate and soils. Journal of the Royal Society of Western Australia 28: 11-87.

Griffin, E.A. and Schoknecht, N.R. (2002). Pre-clearing soil carbon levels in Western Australia. In A. Webb (ed.), Pre-clearing soil carbon levels in Australia, National Carbon Accounting System Technical Report 12: 7-53. Australian Greenhouse Office, Canberra.

Finke, C.W. and Churchward, H.M. (1973). The etched land surfaces of south-western Australia. Journal of the Geological Society of Australia 20: 295-307.

Isbell, R.F. (2002). The Australian soil classification, revised edn. CSIRO, Melbourne.

Isbell, R.F., McDonald, W.S.M. and Ashton, L.J. (1997). Concepts and rationale of the Australian soil classification. Australian Collaborative Land Evaluation Program. CSIRO, Canberra.

Jutson, J.T. (1950). The physiography (geomorphology) of Western Australia. Bulletin 95 (3rd edn). Geological Survey of Western Australia, Perth.

Lange, R.T. (1960). Rainfall and soil control of tree species distribution around Narrogin, Western Australia. Journal of the Royal Society of Western Australia 43: 104110.

McArthur, W.M. (1991). Reference soils of south-western Australia. Australian Soil Science Society (W.A. Branch), Perth

McArthur, W.M., Churchward, H.M. and Hick, P.T. (1977). Landforms and soils of the Murray River catchment area of Western Australia. Division of Land Resource Management Series 3. CSIRO, Perth.

McDonald, R.C., Isbell, R.F., Speight, J.G., Walker, J. and Hopkins, M.S. (1990). Australian soil and land survey field handbook. Inkata Press, Melbourne.

McKenzie, N.L., Gibson, N., Keighery, G.J. and Rolfe, J.K. (2004). Patterns in the biodiversity of terrestrial environments in the Western Australian wheatbelt. Records of the Western Australian Museum Supplement 67: 293-335.

Mulcahy, M.J. (1973). Landforms and soils of southwestern Australia. Journal of the Royal Society of Western Australia 56: 16-22.

Mulcahy, M.J. and Hingston, F.J. (1961). The development and distribution of soils of the YorkQuairading area, Western Australia, in relation to landscape evolution. Soil Publication 17. CSIRO, Perth.

Northcote, K.H. (1979). A factual key for the recognition of Australian soils. Relim Technical Publications, Adelaide.

Northcote, K.H., Bettenay, E., Churchward, H.M. and McArthur, W.M. (1967). Atlas of Australian soils, sheet 5. Perth-Albany-Esperance area. CSIRO/Melbourne University Press, Melbourne.

Pate, J.S., Verboom, W.H. and Galloway, P.D. (2001). Cooccurrence of Proteaceae, laterite and related oligotrophic soils: coincidental associations or causative inter-relationships? Australian Journal of Botany 49: 529-560.

Percy, H. (2000). Katanning area land resources survey. Land Resources Series 16. Agriculture Western Australia, South Perth.

Prescott, J.A. (1931). The soils of Australia in relation to vegetation and climate. Bulletin 52. CSIRO, Melbourne.

Purdie, B.R. (1993, revised 1995, 1996, 1997, 1998). Natural resource assessment standards - standards used for soil and soil-landscape mapping in Western Australia. Unpublished internal report. Agriculture Western Australia, Perth.

Schoknecht, N. (2002). Soil groups of Western Australia: a simple guide to the main soils of Western Australia 3rd edn. Resource Management Technical Report 246. Agriculture Western Australia, Perth

Shepherd, D.P., Beeston, G.R. and Hopkins, A.J.M. (2001). Native vegetation in Western Australia. Technical Report 249. Department of Agriculture, Perth.

Speight, J.G. (1990). Landform. In R.C. McDonald, R.F Isbell, J.G. Speight, J. Walker and M.S. Hopkins. (1990). Australian soil and land survey field handbook. Inkata Press, Melbourne.

Tille, P, Moore, G and Griffin, E.A. (2001) Soils and landscapes of south-western Australia. In G. Moore (ed.), Soil guide, a handbook for understanding and managing agricultural soils. Bulletin 43. Agriculture Western Australia, Perth.

Verboom, W.H. and Galloway, P.D. (2004). Corrigin area land resources survey. Land Resources Series No. 19. Agriculture Western Australia, Perth.

\section{Electronic appendices are on $C D$ inside the back cover}

